\title{
Concurrent Radio-Chemotherapy Combination in Patients with Advanced Head and Neck Squamous Cell Carcinoma
}

\author{
Jean Bourhis \\ Intitute Gustave Roussy, Villejuif, France
}

Dr. Wilkowski and collaborators [1] report preliminary results of a pilot study evaluating the effect of a new concurrent radio-chemotherapy (RT-CT) combination in patients with advanced squamous cell carcinoma of the head and neck (HNSCC). This trial has included 15 patients with stage IV HNSCC who received mitomycin $\mathrm{C}\left(8 \mathrm{mg} / \mathrm{m}^{2}\right.$ day 1,29$)$ and vinorelbine $\left(25 \mathrm{mg} / \mathrm{m}^{2}\right.$ day $\left.1,8,22,29\right)$ concomitantly to accelerated radiotherapy (RT) (71.6 Gy in 5.5 weeks). This study is one of the most recent in a long list of such clinical trials, and provides some additional information on the effect of adding chemotherapy (CT) concomitantly to altered fractionated RT in this type of cancer.

The benefit of adding CT concomitantly to RT for nonmetastatic HNSCC is now well established and the magnitude of the benefit has been re-confirmed recently by the results of a meta-analysis of 87 trials conducted by the MACH-NC collaborative group (meta-analysis of chemotherapy in head and neck cancer) $[2,3]$. This meta-analysis included more than 16,000 randomised patients. Overall, there was a statistically significant survival benefit of $5 \%$ at 5 years for the use of CT $(\mathrm{p}<0.0001)$. There was also a significant interaction between the timing of CT and survival $(\mathrm{p}<0.0001)$. In the trials in which CT was given concomitantly with RT, the absolute benefit was $8 \%$ at 5 years $(p<0.0001)$, as compared to less than $2 \%$ for induction CT (n.s.). In the concomitant RT-CT group of trials, the magnitude of the benefit was not different according to the type and timing of RT (post-operative, conventional and altered fractionated RT). In addition, there was no difference in this group for survival between the use of monotherapy or multiple drug CT. However, the greatest benefit was seen with platinum-based CT compared with other CT $(\mathrm{p}<0.01)$.

In this context, what have we learned from the Wilkowski pilot study, which used a relatively novel RT-CT combination? A promising early tumour response rate was observed, sug- gesting that mitomycin $\mathrm{C} /$ vinorelbine should be further tested in combination with RT in HNSCC. However, these results should be considered with caution. Indeed, as opposed to the meta-analysis database which provides reliable and mature results based on large numbers, the trial from Wilkowski et al. has very small numbers, was not randomised, and had a very short follow-up.

In 2005, the key question for RT-CT combinations in HNSCC is not only to know whether the tumour control probability can be improved by adding CT to RT, but also whether optimisation of the RT-CT combination may still increase the antitumour effect, while minimizing the increase in acute and late toxicity. In this optimisation process, firstly we would need drugs that can improve not only the local control (as many drugs do with RT) but also to decrease the rate of distant metastases. Secondly, we know that adding concomitant RT does increase both acute and late effects [4, 5] of RT. Hence, we clearly need to minimize side effects, either by modifying RT (intensity modulation [6], hyperfractionation [7]) or by using less toxic drugs. Did Wilkowski et al. really optimise the RT-CT combination, by using concomitant mitomycin $\mathrm{C}$ and vinorelbine? The answer is likely to be no on distant metastases and perhaps might be yes for toxicity, since this regimen combined with accelerated RT proved to induce a severe, but still acceptable acute toxicity, while further follow-up is required to make a statement on late effects. How does this regimen compare with the regimens having used mitomycin $\mathrm{C}$ alone or in combination? In other words what is the benefit of adding vinorelbine? The answer is not clear and would need further investigations, since mitomycin $\mathrm{C}$ alone in some $[8,9]$ but not all [10] randomised trials improved the tumour control probability, as compared to RT alone, with relatively limited toxicity. In other randomized trials, where mitomycin $\mathrm{C}$ was combined with another drug (for instance 5-FU [11]), a benefit was observed.

\begin{tabular}{ll}
\hline KARGER & ( ) 2005 S. Karger GmbH, Freiburg \\
Fax +497614520714 & Accessible online at: \\
$\begin{array}{l}\text { E-mail Information@Karger.de } \\
\text { www.karger.com }\end{array}$ & www.karger.com/onk
\end{tabular}


In conclusion, this study provides some additional information in the field of RT-CT in HNSCC. Given the very small sample size and the very short follow up, the only conclusion relates to its feasibility in a population of very advanced HNSCC patients. Further investigations are needed to know whether this regimen can be any better than more widely used CT-RT regimens, such as CDDP-RT combinations, and how it may compare with new molecular targeted therapies, when combined with RT [12].

\section{References}

1 Wilkowski R, Pachmann S, Schymura B, Dellian M, Schalhorn A, Dühmke E: A new concurrent chemotherapy with vinorelbine and mitomycin $\mathrm{C}$ in combination with radiotherapy in patients with locally advanced squamous cell carcinoma of the head and neck. Onkologie 2005;28:491-495.

2 Cohen EEW, Rosine D, Loh E, Haraf DJ, Dekker A, Vokes EE, Bourhis J: A phase I study of cisplatin, tirapazamine and accelerated re-irradiation in unresectable recurrent head and neck cancer. ASCO 2004: abstr 5511.

3 Pignon JP, Bourhis J, Domenge C, Designe L: Chemotherapy added to locoregional treatment for head and neck squamous-cell carcinoma: three meta-analyses of updated individual data. MACH-NC Collaborative Group. Meta-Analysis of Chemotherapy on Head and Neck Cancer. Lancet 2000;355:949-955.

4 Calais G, Alfonsi M, Bardet E, Sire C, Germain T, Bergerot P, Rhein B, Tortochaux J, Oudinot P, Bertrand P: Randomized trial of radiation therapy versus concomitant chemotherapy and radiation therapy for advanced-stage oropharynx carcinoma. J Natl Cancer Inst 1999;91:2081-2086.

5 Denis F, Garaud P, Bardet E, Alfonsi M, Sire C, Germain T, Bergerot P, Rhein B, Tortochaux J, Calais G: Final results of the 94-01 French Head and Neck Oncology and Radiotherapy Group randomized trial comparing radiotherapy alone with concomitant radiochemotherapy in advanced-stage oropharynx carcinoma. J Clin Oncol 2004;22:69-76.

6 Chao KS, Majhail N, Huang CJ, Simpson JR, Perez CA, Haughey B, Spector G: Intensity-modulated radiation therapy reduces late salivary toxicity without compromising tumor control in patients with oropharyngeal carcinoma: a comparison with conventional techniques. Radiother Oncol 2001; 61:275-280.

7 Horiot JC, LeFur R, N'Guyen T et al.: Hyperfractionation versus conventional fractionation in oropharyngeal carcinoma: final analysis of a randomized trial of the EORTC cooperative group of radiotherapy. Radiother Oncol 1992;25: 231-241.

8 Dobrowsky W, Naude J, Widder J, Dobrowsky E, Millesi W, Pavelka R, Grasl C, Reichel M: Continuous hyperfractionated accelerated radiotherapy with/without mitomycin C in head and neck cancer. Int J Radiat Oncol Biol Phys 1998;42: 803-806.

9 Haffty BG, Wilson LD, Son YH, Cho EI, Papac RJ, Fischer DB, Rockwell S, Sartorelli AC, Ross DA, Sasaki CT, Fischer JJ: Concurrent chemo-radiotherapy with mitomycin $\mathrm{C}$ compared with porfiromycin in squamous cell cancer of the head and neck: final results of a randomized clinical trial. Int J Radiat Oncol Biol Phys 2005;61:119-128.

10 Grau C, Prakash Agarwal J, Jabeen K, Rab Khan A, Abeyakoon S, Hadjieva T, Wahid I, Turkan S, Tatsuzaki H, Dinshaw KA, Overgaard J: Radiotherapy with or without mitomycin $\mathrm{C}$ in the treatment of locally advanced head and neck cancer: results of the IAEA multicentre randomised trial. Radiother Oncol 2003; 67:17-26.

11 Budach V, Stuschke M, Budach W, Baumann M, Geismar D, Grabenbauer G, Lammert I, Jahnke K, Stueben G, Herrmann T, Bamberg M, Wust P, Hinkelbein W, Wernecke KD: Hyperfractionated accelerated chemoradiation with concurrent fluorouracil-mitomycin is more effective than dose-escalated hyperfractionated accelerated radiation therapy alone in locally advanced head and neck cancer: final results of the radiotherapy cooperative clinical trials group of the German Cancer Society 95-06 Prospective Randomized Trial. J Clin Oncol 2005; 23:1125-1135.

12 Bonner JA, Ezekiel MP, Robert F et al.: Continued response following treatment with IMC-C225, an EGFr MoAb, combined with RT in advanced head and neck malignancies. Proc Am Soc Clin Oncol 2000;19: abstr 5. 